\title{
Mutagenic Action of Sodium Azide on Germination and Emergence in Landraces of Phaseolus vulgaris L.on the Jos Plateau Agro-Ecological Zone
}

\author{
Sorishima Mlahaga Liamngee ${ }^{1 *} J_{\text {Joshua Jeremiah Ogah }}{ }^{2}$ Kpadoo Terna Amagu ${ }^{3}$ \\ Emmanuel Hala Kwon-Ndung ${ }^{4}$ Dennis Iorkor ${ }^{5} \&$ \\ Jeff Emmanuel Tervershima ${ }^{6}$
}

\author{
${ }^{1}$ Cyto-genetics and Plant Breeding Research Unit, Department of Plant Science and Technology, \\ University of Jos, Jos, Nigeria. \\ ${ }^{2}$ Department of Biological Sciences, Faculty of Science, Federal University, Kashere, Gombe State, Nigeria. \\ ${ }^{3}$ Department of Forestry Technology, College of Agriculture, Yandev, Benue State, Nigeria. \\ ${ }^{4}$ Department of Botany, Federal University, Lafia, Nasarawa State, Lafia. \\ ${ }^{5}$ Department of Plant Breeding and Seed Science, College of Agronomy, Federal University of Agriculture, \\ Makurdi, Nigeria. \\ ${ }^{6}$ Department of Chemistry, Faculty of Science, Benue State University, Makurdi, Nigeria
}

\begin{abstract}
Phaseolus vulgaris (Common beans) landraces are one of the most cultivated legumes for human consumption on the montaneclimate of the Jos Plateau and is renowned for the production of reasonable quantities of the beans in Africa.Common beans is rich in fiber, micronutrients, minerals and has strong medicinal value. Despite its potential for improving nutrition and poverty reduction, it is highly under-utilized and research efforts to improve the genotypes of the plant found in this area for better productivity are few. A study was thus carried out to access the germination and emergence responses of three landraces of Phaseolus vulgaris (pinto, red kidney and navy) after treatment with sodium azide. Four doses of sodium azide were applied in concentrations of $0.1 \mathrm{M}, 0.04 \mathrm{M}, 0.03 \mathrm{M}$ and $0.02 \mathrm{M}$ for each landrace for both germination and emergence experiments. The results showed that at doses $0.02 \mathrm{M}$ and $0.03 \mathrm{M}$, the pinto indicated significantly $(p<0.05)$ higher mean germination which surpassed the control. All sodium azide doses in the red kidney and pinto had reduced mean germination. Sodium azide reduced the mean emergence of pinto, red kidney and navy at all the doses of sodium azide. The lethality of sodium azide was highest in navy and lowest in pinto. The decrease in germination and emergence was not dose related especially in red kidney and navy. The best response to the mutagen was observed in pinto with higher germination and the least percentage lethality. Sodium azide effectiveness and efficiency were strongest at the $0.1 M$ dose of the mutagen.
\end{abstract}

Keywords:Emergence,Germination,Jos-Plateau,Landraces,Phaseolus vulgaris,Sodium azide

\section{Introduction}

Phaseolus vulgaris (Common beans) is one highly under-utilized plant species in Nigeria with most of the genotypes still existing as landraces. It has adapted to the montane Jos Plateau agro ecological zone which is a recognized bean production area in Africa [1]. It is also one of the most widely consumed legumes in the communities of the area. In Africa, cultivated genotypes are usually restricted to two or three per area[1], on the Jos plateau there are five stably cultivated genotypes. The most common include pinto, navy, red kidney and cranberry. Phaseolus vulgaris, is a typical legume. It belongs to the family Fabaceae. It is cosmopolitan in distribution [2]. In Nigeria, especially on the Jos Plateau, it is referred to as Mangu bean or Achishuru by the local communities.Common beans is a highly nutritive, relatively low-cost protein food. They are among the most sought after of foods for their high protein, minerals and medicinal value. They are also easy to cultivate, do not require much farm inputs as do other food crops and they in turn enrich the soil. Women are responsible for about $70 \%$ of its production. It is high in dietary fibre, micronutrients and a variety of phytochemicals [3]. Mature dry seeds are mostly consumed.Common beans is described as a temperate or subtropical crop. When they occur in the tropics, they are usually found in montane valleys. In other areas, lower down the plateau, very few common beans are grown. Temperatures soaring above $30^{\circ} \mathrm{C}$ can negatively affect flowering and completely prevent seed set above $35^{\circ} \mathrm{C}$. In western more developed countries, the plant plays only a minor dietary role [3] unlike in the rural areas of the developing countries around the world where it is prized and serves as a traditional and staple food for local enclaves [4]. In many parts of the Jos Plateau, particular types of the beans are specially prepared and eaten during marriages and other festive periods. Phaseolus vulgaris has been recognized as a crop that would ensure food security in Sub-Sahara Africa [5] and is of great importance in 
helping to alleviate the problem of malnutrition and diversification of diet in Nigeria and Sub-Sahara Africa as it contributes significantly to the amount of calories and other nutrients in the diet. However, the utilization and acceptance of Phaseolusbeans has always been hampered by many problems such as high amounts of synthesized phytic acid in the seeds and the Hard-To-Cook (HTC) phenomenon which have negatively affected its wider acceptability and utilization. Also, there are still not enough works done on the response of these local genotypes to induced mutation. Breeding efforts and improvement programmes on Phaseolus vulgaris in Nigeria have remained scarce even in areas of primordial and fundamental research. This study is therefore aimed at accessing the effect of sodium azide on the germination and emergence of three Phaseolus vulgaris landraces.The variability created by induced mutation in these genotypes is highly desired to improve its productivity.

\subsection{Location of Experimental Site}

\section{Materials And Methods}

This study was conducted at the Mista-Ali Fadama Experimental site located on the outskirts of Jos, the Plateau state capital. It is a small semi-rural settlement which has a rainy season that lasts from about April to October. The area has a mean annual temperature $26.81^{\circ} \mathrm{c}$ and a mean annual relative humidity of $82.29 \%$, it is elevated above sea level by $1,220 \mathrm{~m}$ and it is aligned along longitude $8^{0} 53^{\prime} \mathrm{N}$ and latitude $9^{0} 57^{\prime} \mathrm{N}$ [6].

\subsection{Cultural practices, Plot Layout and Experimental Design}

The experimental site was neatly cleared out and beds for the seeds were made. Using an experimental field size of $14.8 \mathrm{~m}$ in length and $8.5 \mathrm{~m}$ in width, the experimental field comprised of 3 three equal blocks. Spacing between the blocks was $0.4 \mathrm{~m}$. Each block had 15 equal plots measuring $2 \mathrm{~m} \times 0.98 \mathrm{~m}$ numbering a total of 45 plots for the three blocks. All the treatments were applied on each of the three genotypes including the control which gave 15 treatment combinations in all. They were replicated in the three blocks and completely randomized within the blocks. The Phaseolus vulgaris landraces used were; Pinto (Black in colour), Red kidney (Red in colour), and Navy (White in colour).

The treatments are as follows;

Dose $1\left(\mathrm{D}_{1}\right)=0.1 \mathrm{M}$

Dose $2\left(\mathrm{D}_{2}\right)=0.02 \mathrm{M}$

Dose $3\left(\mathrm{D}_{3}\right)=0.03 \mathrm{M}$

Dose $4\left(\mathrm{D}_{4}\right)=0.04 \mathrm{M}$

Control $\left(\mathrm{D}_{0}\right) \quad=\quad$ No treatment

The seeds were planted 15 per plot, in 3 rows and 5 columns with $0.3 \mathrm{~m}$ spacing between the column and rows. The seeds were planted to a depth of $2.5 \mathrm{~cm}$ [7]. The experiment was thus laid out in a Randomized Complete Block Design (RCBD).The plants were sprayed with insecticides to kill insect pest on the $6^{\text {th }}$ Week After Planting (WAP). Weeding was done using the African hand hoe on the $4^{\text {th }}$ and $8^{\text {th }}$ Weeks After Planting (WAP). The plants were watered thrice weekly till harvest.

\subsection{Treatment of Phaseolus vulgaris Genotypes with Sodium Azide for Germination Experiment}

Dry, healthy Phaseolus vulgaris seeds of the pinto, red kidney and navy genotypes were pre-soaked in distilled water up to ten times their volume, according to their varieties for 4 hours. While they were soaking, the mutagen solutions were prepared for four doses $\left(D_{1}=0.1 \mathrm{M}, \mathrm{D}_{2}=0.02 \mathrm{M}, \mathrm{D}_{3}=0.03 \mathrm{M}, \mathrm{D}_{4}=0.04 \mathrm{M}\right.$, Control $=$ No dose) for each of the 3 genotypes. After soaking, the seeds were air dried for 20 minutes then soaked in the mutagen solutions.According to their genotypes for $1 \frac{1}{2}$ hours. Petri-dishes were prepared by washing with distilled water and cotton wool was placed in each petri dish and was moderately soaked with distilled water. The petri-dishes were then labeled according to the landraces and their respective doses.After the treatment time was over $\left(1 \frac{1}{2}\right.$ hours) the seeds were washed under running water for 30 minutes. 10 seeds were then arranged in each of the prepared petri-dishes according to their varieties and doses. They were then stored away in an airy well lit lab area for observation. The seeds were watered with distilled water every two days. Readings were taken every day for 16 days by counting the number of germinated seeds in each treatment for each of the three landraces. Germination was measured by the emergence of the radicle form the split testa. Percentage survival was scored on day 16.

\subsection{Treatment of Phaseolus vulgaris Genotypes with Sodium Azide for Field Experiment}

Phaseolus vulgaris seeds of the Pinto, Red kidney and Navy genotypes were pre-soaked in distilled water up to ten times their volume, according to their genotypes for 4 hours. While they were soaking, the mutagen solutions were prepared for four doses $\left(\mathrm{D}_{1}=0.1 \mathrm{M}, \mathrm{D}_{2}=0.02 \mathrm{M}, \mathrm{D}_{3}=0.03 \mathrm{M}, \mathrm{D}_{4}=0.04 \mathrm{M}\right.$, Control = No dose ) for each of the 3 genotypes. After soaking, the seeds were air dried for 20 minutes then soaked in the mutagen solutions. According to their genotypes for $1 \frac{1}{2}$ hours. After the treatment time was over the seeds were 
washed under running water for 30 minutes. The seeds were immediately taken to the field for planting. Percentage survival was scored on the week of harvest. Chlorophyll mutants were scored in the third week, 19 Days After Planting (DAP) and classified according to [8]. Mutation frequency was calculated as percentage of $\mathrm{M}_{1}$ plants per dose while mutagenic effectiveness and efficiency were calculated based on the formula suggested by [9].

\section{Results}

Table 1: Analysis of Variance for Germination in three genotypes of P. vulgaris treated with Sodium Azide

$\mathrm{LSD}=\mathbf{1 . 7 0}$

\begin{tabular}{|l|l|l|l|l|l|}
\hline Source of variation & Degree of freedom & Sum of squares & Mean squares & F calc. & F tab. \\
\hline Doses & 4 & 128.5 & 32.12 & 30.5 & $2.69^{*}$ \\
\hline Genotype & 2 & 468.8 & 234.4 & 223.2 & $3.32^{*}$ \\
\hline Dose x Genotype & 8 & 182.1 & 22.76 & 21.67 & $2.27^{*}$ \\
\hline Error & 30 & 31.53 & 1.05 & & \\
Total & 44 & 748.8 & & & \\
\hline
\end{tabular}

Table 2: Effect Of Sodium AzideOn Germination in the Pinto Genotype OfP.vulgaris

\begin{tabular}{|l|l|l|l|l|l|}
\hline $\begin{array}{l}\text { Dose of } \\
\text { Sodium Azide(M) }\end{array}$ & $\begin{array}{l}\text { Mean } \\
\text { Germination }\end{array}$ & $\begin{array}{l}\text { Percentage } \\
\text { Increase } \\
\text { Germination(\%) }\end{array}$ & $\begin{array}{l}\text { Percentage } \\
\text { Decrease In } \\
\text { Germination(\%) }\end{array}$ & $\begin{array}{l}\text { Percentage } \\
\text { lethality(\%) }\end{array}$ & $\begin{array}{l}\text { Percentage } \\
\text { survival(\%) }\end{array}$ \\
\hline $\mathbf{0 . 0 4 M}$ & $8.0^{\mathrm{a}}$ & --- & 3.6 & 20.00 & 80.00 \\
\hline Control & $8.3^{\text {ab }}$ & --- & --- & --- & 83.33 \\
\hline $\mathbf{0 . 1 M}$ & $8.6^{\text {ab }}$ & 30.83 & --- & 13.33 & 86.66 \\
\hline $\mathbf{0 . 0 2 M}$ & $9.3^{\mathrm{b}}$ & 10.75 & --- & 6.66 & 93.33 \\
$\mathbf{0 . 0 3 M}$ & $10.0^{\mathrm{c}}$ & 17.00 & --- & 0.00 & 100.00 \\
Mean & & & 12.49 & 71.10 \\
\hline
\end{tabular}

$\mathbf{L S D}=\mathbf{1 . 7 0} *$ Means with same lettering are not significantly different from each other

Table 3: Effect Of Sodium AzideOn Germination in the Red Kidney Genotype of $P$. vulgaris

\begin{tabular}{|l|l|l|l|l|l|}
\hline Dose of sodium azide & $\begin{array}{l}\text { Mean } \\
\text { germination }\end{array}$ & $\begin{array}{l}\text { Percentage } \\
\text { increase in } \\
\text { germination(\%) }\end{array}$ & $\begin{array}{l}\text { Percentage } \\
\text { decrease in } \\
\text { germination(\%) }\end{array}$ & $\begin{array}{l}\text { Percentage } \\
\text { lethality(\%) }\end{array}$ & $\begin{array}{l}\text { Percentage } \\
\text { survival(\%) }\end{array}$ \\
\hline $\mathbf{0 . 1 M}$ & $0.00^{\mathrm{a}}$ & --- & 100 & 100.00 & 0.00 \\
\hline $\mathbf{0 . 0 3 M}$ & $1.0^{\mathrm{ab}}$ & --- & 90 & 90.00 & 10.00 \\
\hline $\mathbf{0 . 0 2 M}$ & $2.0^{\mathrm{b}}$ & --- & 80 & 80.00 & 20.00 \\
\hline $\mathbf{0 . 0 4 M}$ & $2.0^{\mathrm{b}}$ & --- & 80 & 80.00 & 20.00 \\
Control & $10.0^{\mathrm{c}}$ & --- & --- & -- & 100.00 \\
Mean & & & 87.5 & 30.00 \\
\hline
\end{tabular}

$\mathbf{L S D}=\mathbf{1 . 7 0} *$ Means with same lettering are not significantly different from each other

Table 4: Effect of Sodium Azide on Germination in the Navy Genotype of P. vulgaris

\begin{tabular}{|l|l|l|l|l|l|}
\hline $\begin{array}{l}\text { Dose of sodium } \\
\text { azide }\end{array}$ & $\begin{array}{l}\text { Mean } \\
\text { germination }\end{array}$ & $\begin{array}{l}\text { Percentage } \\
\text { increase in } \\
\text { germination(\%) }\end{array}$ & $\begin{array}{l}\text { Percentage } \\
\text { decrease in } \\
\text { germination(\%) }\end{array}$ & $\begin{array}{l}\text { Percentage } \\
\text { lethality(\%) }\end{array}$ & $\begin{array}{l}\text { Percentage } \\
\text { survival(\%) }\end{array}$ \\
\hline $\mathbf{0 . 1 M}$ & $0.00^{\mathrm{a}}$ & --- & 100 & 100.00 & 0.00 \\
\hline $\mathbf{0 . 0 3 M}$ & $0.3^{\mathrm{a}}$ & --- & 93.47 & 96.66 & 3.33 \\
\hline $\mathbf{0 . 0 4 M}$ & $0.3^{\mathrm{a}}$ & --- & 93.47 & 96.66 & 3.33 \\
\hline $\begin{array}{l}\mathbf{0 . 0 2 M} \\
\text { Control } \\
\text { Mean }\end{array}$ & $1.3^{\mathrm{a}}$ & --- & 71.73 & 86.66 & 13.33 \\
\hline
\end{tabular}

LSD=1.70 *Means with same lettering are not significantly different from each other

Table 5: Interaction between Dose of Sodium Azide and Genotype in the Emergence of Phaseolus vulgaris Seeds After 19 Days

\begin{tabular}{|l|l|l|l|l|}
\hline & Pinto & Red kidney & Navy & Mean \\
\hline Control & 25 & 30 & 14 & $\mathbf{2 3}^{\mathbf{d}}$ \\
\hline $\mathbf{0 . 0 2 M}$ & 28 & 6 & 4 & $\mathbf{1 6}^{\mathbf{c}}$ \\
\hline $\mathbf{0 . 0 3 M}$ & 30 & 3 & 1 & $\mathbf{1 1 . 3}^{\mathbf{b}}$ \\
\hline $\mathbf{0 . 0 4 M}$ & 24 & 6 & 1 & $\mathbf{1 0 . 3}^{\text {ab }}$ \\
\hline $\mathbf{0 . 1 M}$ & 26 & 0 & 0 & $\mathbf{8 . 6}^{\mathbf{a}}$ \\
\hline Mean & $\mathbf{2 6}^{\mathbf{c}}$ & $\mathbf{9}^{\mathbf{b}}$ & $\mathbf{4}^{\mathbf{a}}$ & \\
\hline
\end{tabular}




\subsection{Germination tests of Three Landraces of Phaseolus vulgaris Treated with Sodium Azide}

The pinto germinated the most, also indicating the highest survival percentage among the three genotypes $(71.10 \%$ ) (Table 2). Sodium azide was least injurious on pinto as its percentage lethality was also the least among the three genotypes (12.49) (Table 2). Doses $0.02 \mathrm{M}$ and $0.03 \mathrm{M}$ significantly $(\mathrm{p}<0.05)$ increased beyond the control in their germination percentage, $0.03 \mathrm{M}$ having the highest mean germination (Table 2).

Dose $0.1 \mathrm{M}$ had a $100 \%$ lethality percentage in the red kidney and navy as no single seed germinated (Table 3 and 4). In the red kidney, the control percentage survival was 100\% (Table 3). This dropped to $46.66 \%$ in the navy (Table 4). The highest percentage survival apart from the control among the red kidney treatments was $20 \%(0.02$ and $0.03 \mathrm{M})$ (Table 3). The highest percentage survival in the Navy treatments was the least dose $(0.02 \mathrm{M})$ at $13.33 \%$ apart from the control (Table 4$)$. Sodium azide treatment lead to a decrease in germination of all the doses in both red kidney and navy. Interaction between the dose of sodium azide and the genotype in the study was significant $(\mathrm{P}<0.05)$.

Table 6: Analysis Of Variance for Emergence in three genotypes of $P$. vulgaris treated with Sodium Azide

$\mathbf{L S D}=3.99$

\begin{tabular}{|l|l|l|l|l|l|}
\hline Source of variation & Degree of freedom & Sum of squares & Mean squares & F calc. & F tab. \\
\hline Doses & 4 & 237.2 & 59.3 & 10.4 & $2.69^{*}$ \\
\hline Genotype & 2 & 276.85 & 138.42 & 24.2 & $3.32^{*}$ \\
\hline Dose x Genotype & 8 & 63.15 & 4.15 & 0.79 & $2.27^{\mathrm{NS}}$ \\
\hline Error & 30 & 171.08 & 5.70 & & \\
Total & 44 & 763.32 & & & \\
\hline
\end{tabular}

Table 7: Effect of Sodium Azide on Emergence in the Pinto Genotype of P. vulgaris

\begin{tabular}{|l|l|l|l|l|l|}
\hline Dose of sodium azide & $\begin{array}{l}\text { Mean } \\
\text { emergence }\end{array}$ & $\begin{array}{l}\text { Percentage } \\
\text { increase in } \\
\text { emergence (\%) }\end{array}$ & $\begin{array}{l}\text { Percentage } \\
\text { decrease in } \\
\text { emergence (\%) }\end{array}$ & $\begin{array}{l}\text { Percentage } \\
\text { lethality(\%) }\end{array}$ & $\begin{array}{l}\text { Percentage } \\
\text { survival(\%) }\end{array}$ \\
\hline $\mathbf{0 . 0 4 M}$ & $4.33^{\mathrm{a}}$ & - & 65.63 & 71.11 & 28.88 \\
\hline $\mathbf{0 . 1 M}$ & $4.66^{\mathrm{a}}$ & - & 63.01 & 68.88 & 31.11 \\
\hline $\mathbf{0 . 0 2 M}$ & $6.33^{\mathrm{a}}$ & - & 49.76 & 57.77 & 48.88 \\
\hline $\mathbf{0 . 0 3 M}$ & $7.33^{\mathrm{a}}$ & - & 41.8 & 51.11 & 48.88 \\
\hline $\begin{array}{l}\text { Control } \\
\text { Mean }\end{array}$ & $12.60^{\mathrm{b}}$ & - & - & - & 84.44 \\
\hline
\end{tabular}

LSD=3.99 *Means with same lettering are not significantly different from each other

Table 8: Effect of Sodium Azide on Emergence in the Red kidney Genotype of P. vulgaris

\begin{tabular}{|l|l|c|l|l|l|}
\hline $\begin{array}{l}\text { Dose of sodium } \\
\text { azide }\end{array}$ & Mean emergence & $\begin{array}{l}\text { Percentage increase } \\
\text { in emergence }(\boldsymbol{\%})\end{array}$ & $\begin{array}{l}\text { Percentage } \\
\text { decrease } \\
\text { emergence (\%) }\end{array}$ & $\begin{array}{l}\text { Percentage } \\
\text { lethality(\%) }\end{array}$ & $\begin{array}{l}\text { Percentage } \\
\text { survival(\%) }\end{array}$ \\
\hline $\mathbf{0 . 1 M}$ & $0.00^{\mathrm{a}}$ & - & 100 & 100.00 & 0.00 \\
\hline $\mathbf{0 . 0 3 M}$ & $1.00^{\mathrm{a}}$ & - & 88.45 & 86.66 & 6.66 \\
\hline $\mathbf{0 . 0 4 M}$ & $1.33^{\mathrm{a}}$ & - & 84.64 & 82.22 & 8.88 \\
\hline $\mathbf{0 . 0 2 M}$ & $2.33^{\mathrm{a}}$ & - & 73.09 & 84.44 & 15.55 \\
\hline $\begin{array}{l}\text { Control } \\
\text { Mean }\end{array}$ & $8.66^{\mathrm{b}}$ & - & - & - & 88.31 \\
\hline
\end{tabular}

LSD=3.99 *Means with same lettering are not significantly different from each other

Table 9: Effect of Sodium Azide on Emergence in the Navy Genotype of P. vulgaris

\begin{tabular}{|l|l|c|l|l|l|}
\hline Dose of sodium azide & Mean emergence & $\begin{array}{l}\text { Percentage increase } \\
\text { in emergence (\%) }\end{array}$ & $\begin{array}{l}\text { Percentage decrease } \\
\text { in emergence (\%) }\end{array}$ & $\begin{array}{l}\text { Percentage } \\
\text { lethality(\%) }\end{array}$ & $\begin{array}{l}\text { Percentage } \\
\text { survival(\%) }\end{array}$ \\
\hline $\mathbf{0 . 0 2 M}$ & $0.66^{\mathrm{a}}$ & - & 80.18 & 95.55 & 4.44 \\
\hline $\mathbf{0 . 0 4 M}$ & $0.66^{\mathrm{a}}$ & - & 80.18 & 95.55 & 4.44 \\
\hline $\mathbf{0 . 1 M}$ & $0.66^{\mathrm{a}}$ & - & 80.18 & 95.55 & 4.44 \\
\hline $\mathbf{0 . 0 3 M}$ & $1.00^{\mathrm{a}}$ & - & 69.98 & 86.66 & 6.66 \\
\hline $\begin{array}{l}\text { Control } \\
\text { Mean }\end{array}$ & $3.33^{\mathrm{a}}$ & - & - & - & 22.22 \\
8.44
\end{tabular}

LSD=3.99 *Means with same lettering are not significantly different from each other

Table 10: Mutagen Effectiveness and Efficiency per dose of Sodium Azide in Phaseolus vulgaris

\begin{tabular}{|l|l|l|c|c|}
\hline $\begin{array}{l}\text { Dose of } \\
\text { odium azide } \\
(\mathbf{m M})\end{array}$ & $\begin{array}{l}\text { Percentage } \\
\text { lethality } \\
\text { per dose }(\mathbf{L})\end{array}$ & $\begin{array}{l}\text { Mutation } \\
\text { frequency } \\
(\mathbf{M})\end{array}$ & $\begin{array}{l}\text { Mutagen effectiveness } \\
\mathbf{M} \mathbf{~ 1 0 0}\end{array}$ & $\begin{array}{l}\text { Mutagen efficiency } \\
\mathbf{M} \text { x t 100 }\end{array}$ \\
\hline 100 & 71.11 & 13 & 8.66 & 18.25 \\
\hline 20 & 57.77 & 2 & 6.66 & 3.48 \\
\hline 30 & 62.22 & 3 & 6.66 & 3.21 \\
\hline 40 & 65.55 & 3 & 5.0 & 3.05 \\
\hline
\end{tabular}




\subsection{Emergence of Three Landraces of Phaseolus vulgaris Treated with Sodium Azide}

The sodium azide doses reduced the emergence of all the pinto treatments used in the study. The highest survival percentage apart from the control was $0.03 \mathrm{M}$ and $0.02 \mathrm{M}(48.88 \%)$ (Table 7). The highest lethality was $71.11 \%$ at dose $0.04 \mathrm{M}$ with the least mean emergence of 4.33 seedlings. The control almost doubled the highest survival percentage $(48.88 \%$ in $0.03 \mathrm{M}, 0.02 \mathrm{M}$ ) at $84.44 \%$ (Table 7$)$. Some seeds germinated but died before they completely emerged. Sodium azide dose $0.1 \mathrm{M}$ was completely lethal in the red kidney genotype as there were no emerged seedlings (Table 8). No dose performed better than the control. The best performing Navy dose were $0.02 \mathrm{M}, 0.04 \mathrm{M}$ and $0.1 \mathrm{M}$ at $4.44 \%$ survival rate. The best performing dose in the Navy treatment was $0.03 \mathrm{M}$ at $6.66 \%$ survival percentage. The increase in lethality was not dose related.

\section{Discussion \\ 4.1 Germination tests of Three Landraces of Phaseolus vulgaris Treated with Sodium Azide}

Germination is the re-activation of metabolic activity in a seed which results in the growth of the embryo by the emergence of first the radicle, then the plumule from the split testa. This process divided into three distinct stages which are imbibition, cell elongation and cell division [10] each one leading to the next. These processes are associated with the formation and utilization of enzymes which mediate crucial biochemical transformations such as the conversion of stored proteins, carbohydrates or oils depending on the kind of seed in the endosperm to simple ready-to-use substances used to fuel primary growth. The inhibition of respiration [11] disruption of enzyme formation and utilization are common abilities of sodium azide. This could explain the 100 percent lethality in the $0.1 \mathrm{M}$ dose of red kidney and navy (Table 3 and 4). At this dose sodium azide is able to inhibit energy supply and utilization, disrupt enzyme activity such as those of amylase, proteases and lipase responsible for mediating the conversions of starch to maltose, proteins to amino acids and lipids to fatty acids thus preventing essential food processes that can lead to the death of the embryo. Gibberellic acid is known to induce germination [12]. And since the presence of water and gibberellic acid initiates the formation of amylase, sodium azide might have disruptive ability when present with an enzyme or the ions which act as the enzyme cofactor thus bringing the germination process to a complete halt. These activities may still occur on a reduced scale in lower doses of sodium azide.

The mean number of germinated seeds as observed in the experiment did not show a dose dependent decrease in the trend of germination with an increased mutagenic concentration of sodium azide especially in red kidney and navy. This observation disagreed with the work of [13], [14],[15]. The percentage germination showed that pinto had the most germination followed by the red kidney then Navy showing the least germination and obviously been affected the most by the doses of sodium azide.Pinto had two doses $(0.02 \mathrm{M}$ and $0.03 \mathrm{M})$ which increased significantly $(\mathrm{P}<0.05)$ in the number of germinated seeds. This result was also observed by [16] when they recorded an increase in the number of germinated seeds in tomato when treated with sodium azide. The explanations for an increase in germination rates after treatment with sodium azide at doses may lie in the fact that lower doses at certain optimal points in the cell cycle can affect cell metabolic activities differently from normal sodium azide action which has well known lethal effects. [17]suggested that unique points in the cell cycle may affect the course of action of a chemical mutagen.

The $100 \%$ germination percentage for pinto at $0.03 \mathrm{M}$ could be indicative that at this dose, the pinto genotype could be induced to produce mean germination values significantly above the control. The control group for red kidney and navy varieties showed the highest germination within those treatments. This was corroborated by [18] when he reported that the control yielded the highest germination percentage in Triticumestivum. The decrease in germination after increase in mutagenic treatments is due to physical or even physiological disturbances at the cellular level, this may even include chromosomal damage [19]. The presence of sodium azide in the cell can cause point mutations on the chromosomes. Chromosomal disturbances usually lead to changes in the nuclear instructions for the formation of proteins and normal progress of the series of enzyme mediated biochemical processes during germination. Decrease in seed germination of Phaseolus caused by sodium azide may be due to its combined effects on genetic, physiological and cytological processes [19].

Pinto also seemed not only to be able to withstand sodium azide attack better than red kidney and navy but also produced more desirable results in the germination rates as observed at dose $0.02 \mathrm{M}$ and $0.03 \mathrm{M}$, the two lowest doses. It could then be suggested that lower doses of sodium azide such as were used in this study could be used to induce better germination rates in pinto. The behavior of sodium azide in terms of its ability to reduce germination in the red kidney and navy was noted as also was observed by [20]. The best performing genotype was pinto (Table 5) andirrespective of the genotypes, the highest performing dose apart from the control was $0.02 \mathrm{M}$.

\subsection{Emergence of three landraces of Phaseolus vulgaris treated with Sodium Azide}

One cytological activity negatively affected by sodium azide is mitosis [11] and this more or less summarizes the effect of the mutagen on emergence. This is chiefly because the plant growth takes place by the 
multiplication of cells. Cell division especially at the meristematic zones can be impaired thus leading to the incapacity for organ development as sodium azide is known to delay the onset of mitosis and hormonal activity critical for early growth [21]. Enzyme action which works by a correct array of charged and uncharged or hydrophilic and hydrophobic areas on its binding surface [12] could also be impeded by the disrupting of this correct pattern thus disabling the active site. Since sodium azide shows inhibitory action the energy supply system of the cell, all energy related activities will slowly come to halt, killing the seedling before or just after emergence especially at high doses. This can be conveniently done by negatively affecting the oxidation and reduction reactions involved in the transfer of energy, releasing energy at random. If this energy is unregulatorily released all at once, most of it would be dissipated as heat and it will be of no use to the cell, but it will also result in the rise of temperatures to a lethal levels which will initially slow or completely stop temperature sensitive reactions such as enzyme activity and ultimately result in the death of the cell [12]. This can explain the poor emergence and high lethality in all the three genotypes used. None of the genotypes produced positive emergence values. It was more of a matter of which genotype succumbed more to the mutagen attack in which case navy was more susceptible and pinto least susceptible.

As observed, some seeds germinated but died while still half emerged, only traces of the hypocotyl showing above the soil. The understanding that in the epigeal germination of Phaseolus vulgaris, photosynthesis does not take place in the germinated seedling until the seed leaves are pulled out of the soil by the hypocotyl leaves it with the endosperm as its only and exhaustible food source. The death of the un-emerged seedling is ensured by disruption of enzyme mediated pathways responsible for the continued conversion of stored food to simple absorbable molecules before photosynthesis is possible, reducing survivability [21]. Now even when emergence progresses to the energy capturing stage, the presence of sodium azide is also able to reduce ATP production by the inhibition of the terminal segment of the electron transport chain [22] thus its ability to arrest growth at a very early stage. Sodium azide may also be accessible to newly formed cells even after the seedling has reached the photosynthetic stage not just through the indirect cell entry of the plasma membrane which limits the entry of materials into the cell, preserving its functional integrity but also by wholesale access through narrow strands of cytoplasm which interconnects the protoplasts of neighboring cells and is known as symplastic transport [12]. This could provide for a more direct access of materials and indeed sodium azide to new cells and in larger quantities. This can extend the effect of sodium azide to new cells formed during the initial stages of emergence. The embryonic root is protected by a root cap as it emerges from the seed and finds its way into the soil protecting the delicate and crucial meristematic cells. Its growth is continuous and can only be stopped under adverse conditions [12]. The injurious activity of sodium azide on the cells of the root cap and the meristematic cells which replace the cells of the root cap can render it functionally ineffective, thus exposing the tender root cells to injury and opportunist soil fungi and bacteria which can eventually kill the root hairs and damage the only water source of the seed. This leaves a high probability for the death of the young seedling.

Generally, pinto showed stronger emergence as well as lower lethality rates compared to the other genotypes used in the study. This can be attributed to a significantly higher seed vigor in pinto than the red kidney and navy.There was no dose related decrease in the mean germination or lethality. All the doses showed reduced number of emerged seedlings.

\subsection{Mutagen Effectiveness and Efficiency per dose of Sodium Azide in Phaseolus vulgaris}

The presence and frequency of chlorophyll mutants are indicators of the measure of mutagen effectiveness and efficiency [11] on treated plant subjects. These mutants were observed during the third week in the Phaseolus vulgaris population treated with sodium azide which showed different types of chlorophyll malformations in the leaves of the young plants. These include xanthan yellow, chlorina, viridis and striata. Chlorina and xantha yellow showed the highest frequency. This suggests that genes for xanthophyll production are highly susceptible to sodium azide attack. [11]observed that genes close to the centromere of the chromosome were more prone to mutagen attack than those farther away from it with the less likelihood of recombination given this position, it is less likely that the mutation would be removed by selection. Thus the occurrence of chlorophyll mutations as the most basic forms of mutations after mutagen treatment could give a clue on the position of genes controlling plant pigment on the chromosome. There were no leaf, flower or growth habit mutants, an indication that chromosomal aberrations may have been absent [23] or very mild.

Mutagenic effectiveness is a measure of the frequency of mutations effected by a unit dose of the mutagen [24]. The highest mutagen dose (100mM) effected the highest mutagen effectiveness (8.66) (Table 10). This could mean that this dose of sodium azide $(100 \mathrm{mM})$ would produce better mutagen effectiveness even though there was no dose related increase. This dose was also observed to have the highest number of chlorophyll mutations, an indication of a dose with better mutagen effectiveness. Mutagenic efficiency is the measure or proportion of mutations as compared to unwanted effects such as meiotic abberations, sterility and lethality [24]. Mutagen efficiency was best in the strongest mutagen dose $(100 \mathrm{mM})$ and weakest in the second highest dose $(40 \mathrm{mM})$ (Table 10). Mutagen effectiveness and efficiency both did not show a dose related increase. In this study, sodium azide dose $100 \mathrm{mM}$ produced the best mutagen effectiveness and mutagen efficiency. 


\section{Conclusion}

The verifications of this study indicates that sodium azide was effective in increasing germination in its lower doses $(0.02 \mathrm{M}$ and $0.03 \mathrm{M})$ and had the least lethal effect in pinto. Sodium azide was lethal on the emergence of pinto, red kidney and navy. This decrease in emergence was not dose related. Sodium azide effectiveness and efficiency were both highest at dose $100 \mathrm{mM}$. Breeding programmes can utilize sodium azide to improve on the germination potential of pinto. A higher and wider range of sodium azide doses which may improve germination and emergence especially in the red kidney and navy are recommended for further study.

\section{References}

[1]. C.S. Wortmann, R.A. Kirkby and D.J. Allen, (1998) Atlas of Common Bean (Phaseolus L.) Production in Africa. Cali. Colombia : International Center for Tropical Agriculture.

[2]. H.G.. Muller, An Introduction to Tropical Food Science.(Cambridge University Press Cambridge, UK. 1988.) 490pp.

[3]. M.L. Messina, Legumes and Soybeans: Overview of their Nutritional Profiles and Health effects. Nutr.,70 (3), $1999,4395-4505$.

[4]. D. Atilla, H.Kamil, and E.Melek, Characterization of Breeding Lines of Common Bean as revealed by RAPD and Relationship with Morphological Traits. Pak. J. Bot.42 (6) 2010, 3839-3845.

[5]. M. Namugwanya, J.S.Tenywa, E.Ottabong, D.N. Mubiruand T.A. Basamba, Development of Common Bean (Phaseolus vulgaris L) Production under Low Soil Phosphorus and Drought in Sub Sahara Africa:A Review. Journal of Sustainable Development. 7(5), 2014, 128-139.

[6]. G.O. Obigbesan, Report on Potato Production in Nigeria. (Repot of Participant International Course on Potato Production. Wanengen, Netherland. 1978) pp64-71.

[7]. J.W. Purseglove, Tropical Crops:Dicotyledons(Longman Group, UK Limited, England. 1974) page90

[8]. A. Gustaffson, A mutation Syatem of Chloropyll Apparatus. Lund. Univ. Arsskr. N. F. Avd., 36, 1940, 1-40

[9]. C.F.Konzak, R.A. Nilan, J. Wagner, R.J. Foster, Efficient Chemical Mutagenesis.Rad. Bot. (Suppl.)5, 1965, 49-70.

[10]. E.H. Toole, S.B. Hendricks, H.A. Borthwick and V.K. Toole, (1956) Physiology of Seed Germination. Annual Review of Plant Physiology. 7, 1956, 299-234.

[11]. M. Makeen,,B.E. Suresh, G.R.Lavanya, and K. Archana, Study of Chlorophyll and Macromutations induced by Gamma Rays and Sodium Azide in UrdBean (Vignamungo L. Hepper). African Journal of Agricultural Research.8(47), 2013, 5958-5961.

[12]. P.H. Raven, R.F. Evert andS.E. Eichhorn,Biology of Plants.(Worth Publishers. 33, Irving place, New York. 1992.)

[13]. J.K. Mensah,and B. Obadoni (2007) Effects of Sodium Azide on Yield Parameters of Groundnut (Arachishypogaea L.) African Journal of Biotechnology, 6(6), 2007, 668-671.

[14]. L.G. Roopa, Y. Leena, B.G. Suresh and P.P. Jyoti, Sodium Azide Effect on Biological Parameters and Induced Genetic Variability in Mungbean. Journal of Food Legumes. 24 (1), 2011, 46-49.

[15]. B.P. Mshembula, J.K. Mensah and B.Ikhjagbe, (2012) Comparative Assessment of the Mutagenic Effects of Sodium azide on Some Selected Growth and Yield Parameters of Five Asserssions of Cowpea - Tvu-3615, Tvu- 2521, Tvu-3485 and Tvu-3574. Archives of Applied Science Research.4(4), 2012, 1682-1691.

[16]. A.K. Adamu.and H. Aliyu, Morphological Effects of Sodium Azide on Tomato. Science World Journal.2(4), $2007,9-12$.

[17]. B.V. Conger, and J. V. Carabia, Mutagenic Effectiveness and Efficiency of Sodium Azide Versus Ethyl Methane Sulphonate in Maize: Induction of Somatic Mutations in the $y g_{2}$ Locus by Treatment of Seeds Differing in Metabolic State and Cell Population. Science Direct.46(4) 1977, 285-295.

[18]. P. Srivastava, S. Marker, P. Pandey and D.K. Tiwari, Mutaganic Effects of Sodium azide on Growth and Yield in Wheat (Triticumestivm L. em. Thell.).Asian Journal of Plant Sciences.10, 2011, 190 - 201

[19]. S.E. Mahamune and V.S.Kothekar, Induced Mutagenic Frequency and Spectrum of Chlorophyll Mutants in French Bean. International Multidisciplinary Research Journal.2(3), 2015, 30-32

[20]. A.Biarara, M. Muthuswamy and M. Andargie, Effect of Chemical Mutation by Sodium Azide on Quantitative Traits Variation in SesamumIndicum L. Asian Journal of Biological Sciences. 6,2013, 356-362.

[21]. R. Roychodhury and J. Tah, Chemical action on Seed Germination and Related Agro-Metrical Traits in $\mathbf{M}_{1}$ Dianthus generation. Current Botany.2(8), 2011, 19-23.

[22]. D. Gruszka, I. Szarejko, M. Maluszynki, Sodium azide as a Mutagen. Department of Genetics, Faculty of Biology and Environmental Protection, University of Silesia, 40-032 katomize, jagiellonska, 28, Poland. 2012.

[23]. C. Sander and F. J. Muehlbaur, Mutagenic effects of Sodium Azide and Gamma IrradiationinPisum. Science Direct..Vol17(1), 1977, 43,45-47.

[24]. M. Kousar and G. B. Suresh,Mutaagen Effectiveness of Gamma Rays, Sodium Azide and Their Synegistic Effects in Urd Bean (Vignamungo L.). World Journal of Agricultural Sciences. 6(2), 2010, 234-237. 